\title{
The Federal-state Intergovernmental Relationship in Ethiopia: \\ Institutional Framework and its Implication on State Autonomy
}

\section{Abstract}

Nigussie Afesha*

Intergovernmental forums facilitate negotiation, non-hierarchical exchange of information and cooperation between the institutions of the two levels of government. This article explores the experience of the House of Federation, the Ministry of Federal Affairs and sector by sector harmonization in two federal Ministries and their respective regional bureaus. There is lack of an independent institution in charge of consolidating inter-governmental relation (IGR) and this in turn has led to gaps in the regularity, continuity and effectiveness of the interactions. Save for some provisions of the Constitution dictating non-hierarchal relationship between the federal and regional states, the Ethiopian federation is generally characterized by a top-down relationship which can erode the spirit of partnership. Establishing an appropriate legal framework is thus essential to optimize the role of IGR in the Ethiopian federal system. The House of Federation seems the appropriate institution to organize IGR, and if the current dependence on the executive line remains unchanged, the focal point for IGR should be the Prime Minister's Office owing to its enhanced opportunity to give binding decisions and its ability to control the execution of decisions. Excessive reliance on political party lines evokes the question as to what will happen if opposing parties manage to win elections at federal and regional levels, and whether under such settings the collapse of the Soviet Union could be a prophesy to the Ethiopian federalism as well. Such risks call for stable and formal legal and institutional frameworks of IGR toward harnessing centrifugal forces and nurturing unity within diversity.

\section{Key terms}

Intergovernmental relations, IGR, federalism, state autonomy, Ethiopia.

DOI http://dx.doi.org/10.4314/mlr.v9i2.4

\section{Introduction}

IGR focuses on how different orders of government in federal political systems communicate and collaborate with each other. It encompasses the entire

\footnotetext{
* Nigussie Afesha, Lecturer at Hawassa University, College of Law and Governance, School of Law. I thank Beza Dessalegn, Bisrat Mulugeta and Anbesie Fura for their comments and suggestions. I am also grateful to Elias N. Stebek and the anonymous reviewers for their contributions toward the improvement of the article.
} 
complex and interdependent relations among various spheres of government in legal, financial and administrative matters and policy coordination. There are various types of political arrangements or structural political organizations with varying degrees of relevance and utility. ${ }^{1}$ An effective structure in a political organization is conceived as the bedrock on which the state is erected. ${ }^{2}$ It is also described as an indispensable determinant of administrative efficiency in any state. One of such structural political organizations which have weathered the test of time is federalism. ${ }^{3}$ The idea of federalism presupposes the existence of tiers of government with defined competence and dominion of jurisdiction on the same land. ${ }^{4}$ Powers and functions of each government are outlined as part of the division of power and their sovereignty is also maintained. However, it does not necessarily mean that the division of powers and functions between the central government and constituent units remains fixed on permanent basis. It rather involves a continuous process of political bargaining between the centre and the federation units. ${ }^{5}$ To this end, the synergy among the different levels of government needs to be backed by well-designed and institutionalized intergovernmental relations. ${ }^{6}$ IGR is a vital norm and continues as a widely shared and one of the most common characteristic of any federation. ${ }^{7}$ It regulates and enhances communication between the institutions of the two levels of government that have defined jurisdictions and are supreme within their respective powers.

IGR focuses on how different orders of government in federal political systems communicate and collaborate with each other. It encompasses the entire complex and interdependent relations among various spheres of government with respect to co-ordination of public policies. ${ }^{8}$ IGR as a concept is commonly

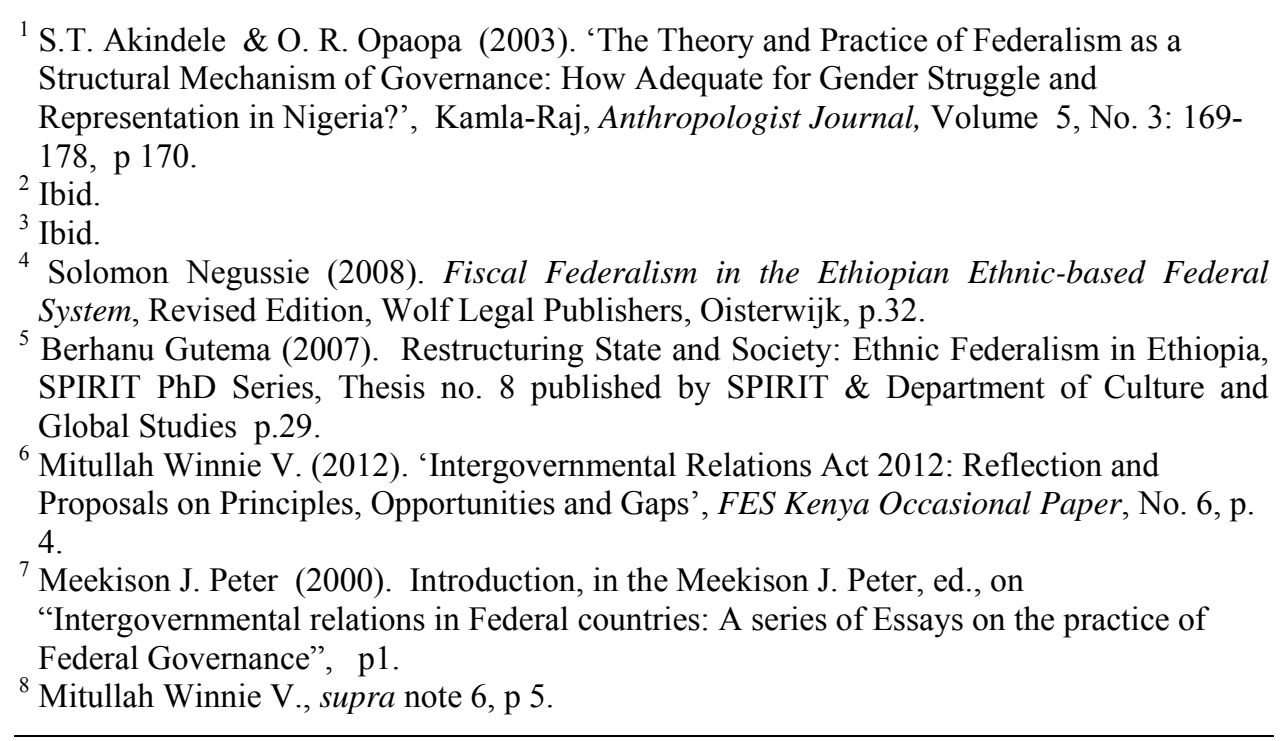


used to refer to relations between and within levels of government that facilitate the attainment of common goals through cooperation and interactions. ${ }^{9}$ These relations and interactions occur through policy alignment, reporting requirements, fiscal grants and transfers, the planning and budget as well as informal knowledge sharing and communication among officials. ${ }^{10} \mathrm{With}$ this in mind, establishment of permanent forums of intergovernmental bond has crucial roles in negotiation, non-hierarchical exchange of information as well as facilitation of cooperation between the institutions of the two levels of governments. ${ }^{11}$ This eventually will bring mutual respect and confidence between the various levels of government. ${ }^{12}$

It may be argued that intergovernmental cooperation is both an inevitable and desirable feature of federal political systems. Given the importance of IGR in a federal system in enhancing negotiation, maintaining non-hierarchical exchange of information as well as facilitation of cooperation, an important question facing many federations is the extent to which modern constitutions should recognize and regulate intergovernmental interaction. ${ }^{13}$ In many federations, there are intergovernmental councils, commissions, and committees, ${ }^{14}$ and their interaction depends on the type of federation and subject matter.

In Ethiopia, the Constitution provides for a dual governmental structure along with separate jurisdiction to each level of government. ${ }^{15}$ Although the jurisdictions of the federal government and the member states are distinctly delineated, there are important constitutional provisions that underline the need for consultation, coordination and collaboration. It is possible to argue that the federal government and the constituent units are interdependent in a wide range of matters. The preamble of the FDRE Constitution emphasizes the need to form, "one economic community...with sustainable and mutually supportive conditions ..." In the first dimension of the functional interface between the two levels of government, the federal government is authorized to formulate and implement the overall social, economic and development policies and strategies of the Country, while the jurisdiction of the regional governments is limited to

\footnotetext{
${ }^{9}$ Ibid

${ }^{10} \mathrm{Ibid}$

${ }^{11}$ Assefa Fiseha (2009). 'The system of Intergovernmental relationship (IGR) in Ethiopia: in search of institution and Guidelines', Journal of Ethiopia law, vol. 23 No.1 PP 96-131 pp. 107-108.

12 Ibid, p 108.

13 Patz, Tom (2005). 'Ethiopia', in Ann Griffith (ed.), Handbook of federal countries. Montreal and Kingston: McGill-Queens University Press.

${ }^{14}$ Watts, R. (2001). Comparing Federal Systems. $2^{\text {nd }}$ ed. Montreal and Kingston: School of Policy Studies - Queen's University.

${ }^{15}$ See article 50(2) of the FDRE Constitution.

${ }^{16}$ See the preamble of the FDRE Constitution.
} 
preparing social, economic and development policies and strategies that are going to be implemented in their specific regions. ${ }^{17}$

The second dimension relates to matters of education, health, science, technology, protection of cultural and historical legacies. In these matters, the federal government sets the national standards and basic policies, while the regional states are the conduits for the protection and promotion of the language, culture and history of their respective constituent ethnic communities. ${ }^{18}$ Third, while the federal government is responsible to enact laws for the utilization and conservation of land and other natural resources ${ }^{19}$ the administration of such laws is left for the regional states. ${ }^{20}$ Fourth, the judicial authority of the federal High Court and First-Instance Court is delegated to state Supreme Court and High Court respectively. ${ }^{21}$ Fifth, although each level of government is, in principle, assigned executive authority for which it has exclusive legislative power, federal laws are, in practice, largely executed through the regional states. Perhaps more importantly, extensive interaction is envisaged in the fiscal domain which involves sharing of revenue, provisions of grants and loans, and the auditing and proper utilization of grants allocated to the regions. ${ }^{22}$

In spite of the wide range of affairs which require continuous synergy among the federal and regional state governments, there are hardly enough provisions in the Constitution to regulate IGR. ${ }^{23}$ The Constitution seems to have loopholes in terms of offering sufficient provisions for intergovernmental cooperation. Even the existing rudimentary provisions remain largely unimplemented. ${ }^{24}$ Other laws and political parties have also failed to create sufficient permanent institutional mechanisms to deal with intergovernmental issues. Hence, IGR is a notion which is given relatively little attention. This study, therefore, explores the current IGR framework in Ethiopia, including policies and structural mechanisms with a view to determine the extent to which these have been anchored.

There are two sets of intergovernmental relation -vertical and horizontal. ${ }^{25}$ The vertical relation focuses on the relation between the federal government and

\footnotetext{
${ }^{17}$ See article 51(2) cum 52(2)(c) of the FDRE Constitution.

${ }^{18}$ See article 51(3) of the FDRE Constitution.

${ }^{19}$ See article 55(2) (a) of the FDRE Constitution.

${ }^{20}$ See article 52(2)(d) of the FDRE Constitution.

${ }^{21}$ See article 78(2) of the FDRE Constitution.

${ }^{22}$ Solomon Negussie, supra note 4, p 98.

${ }^{23}$ Ibid, p 108.

24 Ibid.

${ }^{25}$ David Cameron (1999). Structure of Intergovernmental Relationship a paper presented at the International conference on Federalism, Mont-Tremblant, October 1999, Background paper, p. 1.
} 
constituent units or between constituent units and local governments, whereas the horizontal relation involves inter-state or inter-local relations. ${ }^{26}$ This article examines the practices of federal-state intergovernmental relationship in Ethiopia. The institutions which are presented in this article were purposely selected for investigation on the basis of their relative importance and accessibility and their experience in serving as a focal point for the intergovernmental relation. Institutions that have relatively wider common matters in relation to other institutions were preferred. In this regard, four federal level institutions and two institutions from regional governments are selected for investigation. Their experience with regard to organizing intergovernmental relation has been examined.

The first section of this article offers a conceptual overview of IGR and highlights the theoretical foundations of intergovernmental relationships. Section two, discusses the necessity of intergovernmental collaboration within a federal system. The third section deals with models of intergovernmental relationships and briefly addresses the nature and features of dual and executive models of intergovernmental relations. Section 4 highlights the mechanism of organizing and institutionalizing intergovernmental relationship in a given federal political system. The fifth section briefly explores IGR in Ethiopia and its development following the enactment of the FDRE Constitution. It also presents the institutional framework of IGR and its implication on the autonomy of the states.

\section{Conceptual Overview of IGR}

Intergovernmental relations are of growing concern among governments and political scientists ${ }^{27}$ as they are ubiquitous and pervasive in all federal systems. This emanates from the inevitable facts of interdependence among levels of governments; complexities of the contemporary policy agenda; and the impossibility of drawing clear and separate lines of responsibility among tiers of government. ${ }^{28}$ It may be argued that intergovernmental relations are not about neatly defining and defending areas of competency but rather about co-operation between organs of the state in different spheres of government. ${ }^{29}$

${ }^{26}$ Deil S. Wright (1974). 'Intergovernmental Relations: An Analytical Overview', Annals of the American Academy of Political and Social Science, Vol. 416, Intergovernmental Relations in America Today (Nov., 1974), pp. 1-16 p. 2.

${ }^{27}$ Pattison Mark (1980). 'Intergovernmental Relations and the Limitations of Central Control: Reconstructing the Politics of Comprehensive Education', Oxford Review of Education, Vol. 6, No. 1, pp. 63-89, p. 64.

${ }^{28}$ George Anderson (2008). Federalism: An Introduction, Oxford University Press. p. 59.

29 Department of Provincial and Local Government (the dplg) Practitioner's Guide to Intergovernmental Relations in South Africa, Website: www.dplg.gov.za 
According to Watts, "Intergovernmental relations are conventionally defined as interaction between governmental units of all types and levels within a political system". ${ }^{30}$ The wording "all types" signifies the existence of formal and informal IGR. The informal aspect of IGR results from the exchange of information either by letter, telephone or other similar means. ${ }^{31}$ On the other hand, formal IGR is established by the Constitution, subsequent laws or by intergovernmental convention. ${ }^{32}$ While informal processes involve direct communication between functionaries of different levels of governments, the formal institutions and processes are in the form of meetings, conventions, or conferences involving legislators, ministers, officials, and departments of different ministries of federal functionaries.

The words "all levels" imply "top down or bottom up relationship", or they may refer to collateral relationship among the constituent units. This involves two sets of relationships -vertical and horizontal ${ }^{33}$ The vertical relation can be the relation between the federal government and constituent units or between constituent units and local governments. The horizontal relation, as stated above, involves inter-state or inter-local relations. ${ }^{34}$ It is important to note that such relationship becomes inevitable in areas which involve concurrent power or policy framework on shared programs between the federal government and the regions..$^{35}$ Coordination of polices on shared programs is thus one of the factors which necessitate intergovernmental cooperation within a given federal system.

\section{The Rationale for Intergovernmental Relations}

The establishment of permanent forums of intergovernmental bond plays a crucial role in negotiation, non-hierarchical exchange of information as well as facilitation of cooperation between the institutions of the two levels of government. ${ }^{36}$ This will bring mutual respect and confidence between the levels of government. There could be various factors that render cooperation as well as coordination between or among the tiers of government ${ }^{37}$ indispensable.

First, the difficulty of giving clear-cut jurisdiction for each level of government renders IGR necessary because "it is impossible to have a

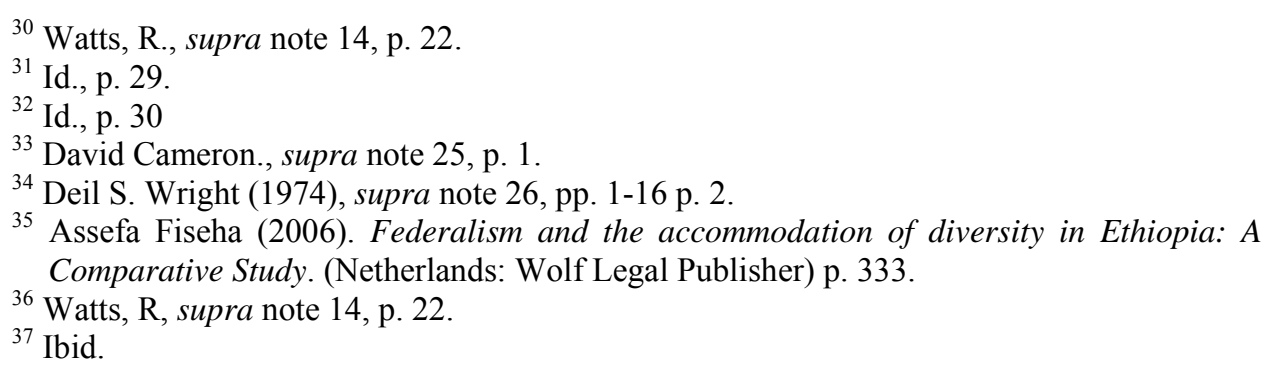


watertight distribution of administrative or legislative jurisdiction among governments or to avoid overlaps of function". ${ }^{38}$ Shared programs are inevitable, and intergovernmental cooperation is one of the mechanisms of mitigating conflict in the course of such programs. In this respect, Steytler argues that "conflict between tiers of states may be inevitable because they would often compete for the same powers and resources. Where such conflict occurs, they should be settled in the spirit of [cooperation]". ${ }^{39}$ In this sense, IGR mechanisms are viewed as instruments that facilitate negotiation on matters that involve disagreement. Such interaction creates mutual understanding between the federal and regional governments.

Second, intergovernmental relation can serve as "a means to adapt changing circumstances without having to resort to formal constitutional amendments". 40 There is principle of co-operation implied from the concept of federalism that could overcome gaps in power distributions. The aim of intergovernmental relation is to make adjustment in the existing constitutional distribution of power rather than going through a rigorous constitutional amendment process, especially where the formal constitutional amendment procedures are rigid and unworkable. ${ }^{41}$

Third, having effective and efficient intergovernmental relation will help to achieve, inter alia, policy coordination, consultation, sharing of experience between the tiers of governments and among states/units/regions. ${ }^{42}$ In a nutshell, most federal systems have developed some kind of informal and formal structural processes to coordinate and facilitate inter-governmental relations. ${ }^{43}$ Although these are the potential explanations that demand intergovernmental relation to be rooted within the federal system, their type is influenced by the models of IGR.

\section{Models of Intergovernmental Relation}

A federal system usually requires a combination of two orders of government that are competent and autonomous in their respective spheres and have concurrent powers which can be exercised jointly. Here, what is important is

\footnotetext{
${ }^{38}$ Ibid

${ }^{39}$ Steytler Nico (2005). 'Republic of South Africa', in John Kincaid and G. Alan, eds., Institutional Organs, Structure and Change in Federal Democracies. Montreal and Kingston: McGill-Queens university press, p. 176.

${ }^{40}$ Watts, R, supra note 14, p. 26.

${ }^{41}$ Ibid.

${ }^{42}$ Carolyn M. Johns, Patricia L. O‘Reilly, Gregory J. lnwood (2007). 'Formal and informal dimensions of intergovernmental administrative relations in Canada', Canadian Public Administration Journal, Vol. 50, No. 1, pp. 21-41, p. 33.

${ }^{43}$ Ibid.
} 
how these tiers of government, which are coequal and autonomous, cooperate in order to improve the federal practice of the country, especially in the area of shared functions. In this respect, there are two models that deal with intergovernmental relations in a federal structure.

\subsection{Dual/Competitive Model}

The older federations were born in an era of limited government; hence their founders saw little need for formal mechanisms to manage interdependence. ${ }^{44}$ For that matter, they did not anticipate the overlapping of power and interdependence between the central government and member units of the federation. In effect, they did not build formal intergovernmental arrangements into their constitutional systems. ${ }^{45}$ This model focused on separate or divided model of federalism, in which, each government would be responsible for both lawmaking and the implementation of a defined list of responsibilities. ${ }^{46}$ The foundation of this model is the accountability of each executive to its own legislature.

This model mainly focuses on the existence of inherent competition between the levels of government. According to Richard, "the characteristic of the competitive model is that it assumes the existence of inherent competition for power between the federal and state governments and one can give power only at the expense of the other." ${ }^{47}$

The emphasis of this model rests on the competition of the levels of government leaving no room for a pattern of political integration between them. According to this line of argument, state power should be divided between the two tiers of government so that each of them operates independently; this denotes a spirit of competition and rivalry between the center and the region. ${ }^{48}$ Consequently, intergovernmental relations among the levels of government are likely to be minimal.

This does not however mean that the constitutions of the adherents of this model are utterly silent on some critical issues of intergovernmental relationship. In an era of complex, all pervasive governance, interdependence and overlapping functions grow exponentially, with the attendant risks of contradiction and duplication, requiring the development of extensive

\footnotetext{
${ }^{44}$ Simeon Richard. (2000). 'Conclusion' in the Meekison J peter, ed., on "Intergovernmental relations in Federal countries: A series of Essays on the practice of Federal Governance" p. 92.

${ }^{45} \mathrm{Ibid}$

${ }^{46}$ Solomon Negussie, supra note 4, p. 38.

${ }^{47}$ Assefa Fiseha (2006), supra note 35, p. 369.

${ }^{48}$ Solomon Negussie, supra note 4, p.38.
} 
mechanisms of intergovernmental relations. ${ }^{49}$ Even if there are such types of constitutional framework, in practice, the various levels of government in a federation have frequent interactions in legal, financial and administrative matters. ${ }^{50}$ This shows that interaction between the levels of government is unavoidable.

\subsection{Executive/ Cooperative Model}

This model is in sharp contrast to the dual federalism. It can be described as a "shared" or "integrated" federalism, and emphasizes not only on distinct status and roles of the different orders of government, but it also gives due attention to their collective responsibility in legislation, implementation ${ }^{51}$ and other avenues. The experience of federations throughout the world indicate that it is neither possible nor -in some cases- desirable for member governments in a federal polity to exercise their powers entirely in isolation from each other. ${ }^{52}$ It is understandable that the distribution of power in a federal system is not based on the assumption that the subject of government activity is isolated from each other. However, if there are matters that are specifically given to different levels of government and where they need to be regulated by different and competing orders of government, each tier of government carries out its functions independently. Conversely, if a given function needs joint arms of both levels of government, they can work together.

This cooperative model suggests that federal and state governments do not operate in isolation as portrayed by the competitive model but rather they interact frequently. In this regard, it is pointed out that:

... [T] he interdependence/overlapping model gives emphasis to the existence of shared power and responsibilities among the different levels of government. In a nutshell, it states that many areas of policy require federal, state and local involvement; that in modern federal system, the areas of autonomy and discretion for any single jurisdiction are limited; that several levels of government require more bargaining and negotiation than competition to obtain adequate power influence to carry out programs. $^{53}$

${ }^{49}$ Simeon Richard, supra note 44, p. 92.

${ }^{50}$ Solomon Negussie, supra note 4, p. 38.

${ }^{51}$ Simeon Richard: supra note 44, p. 92.

52 Saunders Cheryl. (2003). Formal and Informal Institutions and Mechanisms of Intergovernmental Relations in Australia, a paper presented on Mechanisms of Intergovernmental Relations: International Experiences and Challenges for Brazil from 17 and 18 September 2003, Brazil , p. 1.

${ }^{53}$ Assefa Fiseha (2006), supra note 35, p. 369. 
In this context, federal-state relationship has been considered as the important aspect of the federal system. Intergovernmental relation, in effect, is regarded as a basic pillar of cooperation that permeates the federal arrangement and that is used as an instrument to facilitate compromise if conflict arises out of various interests. This model requires the constitution or legislation to spell out for the establishment of IGR institutions and set rules that govern how these institutions will operate in order to manage intergovernmental collaboration. The structural arrangement of this model may vary from federation to federation.

\section{Structure of Intergovernmental Relation}

Co-operation in a federation is not an unqualified good, irrespective of the subject and form. In any federation, therefore, there are questions about when co-operation is appropriate and in what form. ${ }^{54}$ There are many ways by which one can describe, organize, and institutionalize intergovernmental relations. The following dimensions are intended to capture the major aspects of such variations. ${ }^{55}$

\subsection{Arrangements of intergovernmental relation}

The mechanism of intergovernmental relationship varies from one political system to another across federations. ${ }^{56}$ This variation may be attributable to various factors. One may find a formal institution which is established either by the constitution itself or by a subsequent proclamation. Such law is expected to contain detailed rules on how this institution works, including the character and major coordination area in which the institution focuses.

The formal rules of intergovernmental relations are imperative to constrain clientelism and destructive behaviour during the IGR dialogue. ${ }^{57}$ Moreover, these laws encompass the role of both the federal and constituent states in IGR. The laws indicate the area of competence at both levels of government to negotiate and define how IGR institutions function. One of the cardinal reasons for formalizing IGR lies on the benefit that "Institutionalisation brings

\footnotetext{
${ }^{54}$ Saunders Cheryl, supra note 52, p. 2.

${ }^{55}$ Simeon Richard, supra note 44, p. 91.

${ }^{56}$ Peter Söderlund. (2005). The Dynamics of Federalism in Russia: A Study of Formal and Informal Power Resources of the Regional Chief Executives in Russian center-region Relations, Åbo Akademi University Press, Finland, p. 14.

${ }^{57}$ Kincaid John (2000). Intergovernmental relations in the United States of America, in the Meekison J. Peter, Ed. on "Intergovernmental relations in Federal countries: A series of Essays on the practice of Federal Governance" p. 33.
} 
continuity, stability and predictability. Formal functioning mechanisms allow for clear cut action enabling smoother functioning." 58

Notwithstanding these benefits of formal IGR, there are informal intergovernmental relation mechanisms, especially, in those federations whose constitutions do not provide ample provision that regulates intergovernmental matters. Informal IGR, in most cases, may not have "constitutional base", but it emerges through practice or evolves over time. The practice shapes the overall structure and character of IGR. Of course, constitutions may incidentally indicate the areas where the federal and the regional governments can work together in general or the sector by sector cooperation in particular. However, in the absence of an institution which is dedicated to IGR, it is clearly felt that intergovernmental interaction between different levels is not a regular affair. The informal ways of IGR are fluid and ad hoc that may develop in line with changing circumstances and existing political turmoil; and in effect, due attention should be given to formal IGR.

\subsection{Balance of power among governments in the IGR forums}

The concept of federalism is based on the idea of partnership which presupposes the political actors of the federal and state governments to act and discuss their issues on coequal terms. By logical extension we may conclude that IGR circumvents hierarchical relation between the center and regional governments. In this regard, Assefa considers "the idea of negotiation as an inherent aspect of the IGR process and structure" and he notes that "the process should not be based on the dictates of one level of government over the other, but should have some elements of bargaining and negotiation". 59 In principle, the predominant impression is one of relative equality between the two orders of government.

Unless federal and state governments interact on coequal terms and spirit of partnership, the federal political union which has been developed through series of negotiation would be defeated. Hierarchy and inequality are likely to lead to very different dynamics. The idea of non-hierarchal relationship and the spirit of partnership would make clear in advance number of issues such as the mechanism of bringing the political acts of the federal and regional states to the round table discussion and the manner in which the agenda is set. Whether regional states can request the federal government for negotiation would also be clearly stipulated including issues such as who would chair such a negotiation and, how the institutions should be composed of.

\footnotetext{
${ }^{58}$ Ofilia Saavedra \& K. K. Kailash (2002). What are Effective Approaches to Intergovernmental Relations? A paper presented at $4^{\text {th }}$ International Conference on Federalism: Unity in Diversity Young Professionals, April 22, 2002. p 8.

${ }^{59}$ Assefa Fiseha (2009), supra note 11, p. 115.
} 


\subsection{Intergovernmental institutions as decision-making bodies}

The formal approach of intergovernmental relations presupposes the establishment of one or more institutions in charge of regulating the matter. The establishment of these institutions requires defining their mandates and decision making competences. ${ }^{60}$ Intergovernmental deliberations primarily involve exchanging information and ideas; and they provide a forum for discussion. ${ }^{61}$ On the one hand, intergovernmental institutions are mandated to process bargaining, negotiation, and persuasion between levels of government, while both levels of government remain responsible to their own legislatures and electorates for the actions they take. ${ }^{62}$ At the other extreme, there are intergovernmental institutions that can make formal decisions, binding on all the partners. $^{63}$

There is strong resistance against the assignment of binding powers to nonelected intergovernmental bodies. This is because accountability of governments to each other would potentially undermine the accountability of each levels of government to its legislature. In integrated federations, on the other hand, where homogeneity and consistency are highly valued, binding intergovernmental agreements are the norm. ${ }^{64}$

\subsection{Focal point for institutional design}

The institutional design of IGR lies in the broader institutional structure or framework, within which federalism and IGR are embedded. Be it formal or informal, it must indicate the place where this institution should be attached. ${ }^{65}$ The institutional design should answer the following queries. Should intergovernmental relationships be based on the executive line or other nongovernmental institutions? Where should the focal point be? Does it need to be an independent institution or should it be attached to another federal institution?

Indicating the place where the institution is situated is vital. This perhaps guarantees easy enforceability of the decisions. Normally, intergovernmental relations take the form of relationship between the executives of the two orders of government. ${ }^{66}$ This implies that intergovernmental relation can be facilitated through different channels, structure and processes ${ }^{67}$ Party channel is one of them. For such a situation to exist there must be one effectively organized and

\footnotetext{
${ }^{60}$ Ibid, p.107,

${ }^{61}$ Simeon Richard, supra note 44,99 ,

${ }^{62}$ Ibid,

${ }^{63} \mathrm{Ibid}$

${ }^{64} \mathrm{Ibid}$

${ }^{65}$ Assefa Fiseha, (2009), supra note 11, p 111

${ }^{66}$ Ibid , p 108

${ }^{67}$ Watts, R. (2001), supra note 14, p. 23
} 
highly disciplined party that controls all levels of government: both at federal and regional levels. ${ }^{68}$ With an integrated party system in which national parties are able to win support across all or most regions, and in which national and provincial/state parties are closely linked, with considerable mobility of leadership from one level to another, much of the accommodation between the center and regions will take place in the course of party politics and in the national political arena. ${ }^{69}$

\section{Party System versus Intergovernmental Relations}

In full-fledged democracies, political parties compete to assume state power. The structure of political parties, and their internal practices, policies and pattern of interaction can affect the workings of federations. ${ }^{70}$ These factors can have a profound impact upon the functioning of federations. For instance, centralized parties tend to centralize political power and decision-making and may create trends against the division of power in federations. ${ }^{71}$ By the same token, if splintered parties rule the regional states or if region-based parties are very strong, it poses a challenge in the management of a federation. ${ }^{72}$

As William Riker notes, "the structure of the system of political parties is what encourages or discourages the maintenance of the federal bargaining". 73 The implication of this argument is that different forms of intergovernmental interactions may be desirable depending on the political structure of the country. This is not without reason; the experience of intergovernmental relations in various federal systems points to the existence of a great variety of arrangements. Thus the argument is that, intergovernmental relations can be facilitated through different channels, structure and processes. ${ }^{74}$ Party system and party channel among other things, are among the various mechanisms. For such a situation to exist there must be one effectively organized and highly disciplined party that controls all levels of government: both at federal and the regions. $^{75}$

The nature of political parties and their internal working procedures has an impact on the working of a federation. If one homogeneous party controls both

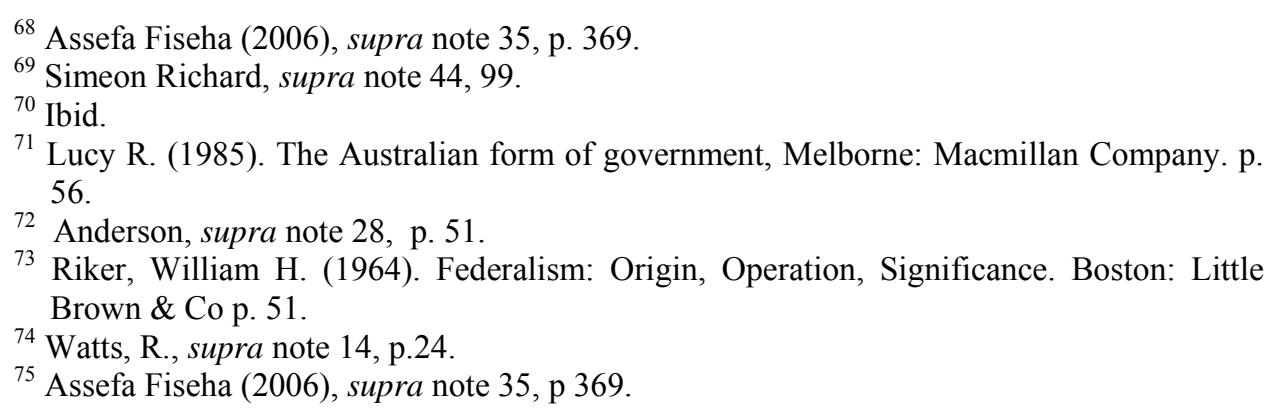


levels of government, there would be no occasion for intergovernmental conflicts. ${ }^{76}$ But, in majority of the federations, it is usually unlikely that there would be one party dominating both levels of government for a long period of time. On the other hand, if diverse parties are in control of the different levels, we can expect high level of intergovernmental conflicts and competition.

\section{Intergovernmental Relationship in Ethiopia: Institutional Framework and its Implication on State Autonomy}

The FDRE Constitution requires both tiers of government to preserve and maintain constitutional order throughout the federation. ${ }^{77}$ Despite this major concurrent constitutional responsibility of the federal and regional states, the Constitution contains no explicit reference to intergovernmental cooperation and it does not expressly state the obligations of the respective levels of government in maintaining the constitutional order. There was thus the statutory gap in intergovernmental relations and statutory institutions were not established with an explicit aim of facilitating the cooperation.

In practice, however, various informal intergovernmental forums were established in the Ethiopian federation after the enactment of the Constitution. These forums are principally aimed at paving the way for cooperation and integration between the levels of government. Although meetings were taking place between the federal ministerial offices and regional bureaus, between director generals and technical experts; between regional governments and local governments with their respective offices or sectors, they were largely ad hoc, spontaneous, irregular and often without clear constitutional base. ${ }^{78}$

In federations with parliamentary systems where the predominant role of governmental executives in intergovernmental relations are visible, the institutions and processes for intergovernmental relations usually develop pragmatically rather than by constitutional requirement. ${ }^{79}$ In Ethiopia too, the institutions and processes for intergovernmental relations have been more or less similar to federations with parliamentary systems. ${ }^{80}$ They involve direct communications (via letters or telephone conversations) between the concerned functionaries of federal and regional governments. The various ministries of the federal government have direct and close contact with their corresponding bureaus in regional governments. This close link and interdependence is imperative to carry out their respective responsibilities effectively and in a

\footnotetext{
${ }^{76}$ Id., p. 392.

${ }^{77}$ See article 51(1) cum 52(2)(a) of the FDRE Constitution.

${ }_{78}^{78}$ Solomon Negussie, supra note 4, p. 104.

${ }^{79}$ Assefa Fiseha (2009), supra note 11, p 111.

${ }^{80}$ Ibid.
} 
coordinated manner. It also enhances the capacity of the regional governmental institutions, which compared to the federal government institutions, suffer from lack of adequate human and material resources. For instance, the Federal Ministry of Health and the regional health bureaus work together in a mutually complementary manner in the effort to implement the federal health policies and standards in regional states. ${ }^{81}$ The Ministry also provides technical assistance to the regional health bureaus.

We can also identify other ad hoc mechanisms of intergovernmental relations in Ethiopia. These include conferences, advisory ad hoc bodies, exchange of personal and technical experts, or personal exchange of information between authorities of the levels of governments. ${ }^{82}$ These interactions reveal the inevitability of intergovernmental relations between the federal and regional governments so as to ensure smooth and efficient application of powers and responsibilities. Yet there is the need to look into the institutional framework that has been practiced in Ethiopia along with its implications on the autonomy of regional states.

\subsection{Institutional framework of intergovernmental relationship in Ethiopia}

Usually the mechanisms and structures to carry out IGR functions are the result of both formal and informal arrangements. However, structures may be determined, at least in part, by constitutions, legislation and other more formal agreements. National constitutions often specify revenue and expenditure assignments, but they do not institutionalize elements of intergovernmental machinery, though some countries have extensive constitutional intergovernmental provisions. ${ }^{83}$ Usually, federations manage their intergovernmental relations with less explicit guidance rather than express stipulations in the constitution. ${ }^{84}$ It is through legislation that IGR mechanisms are established and regulated. This means, the legislator passes bills to formalize inter-governmental institutions. Such bills commonly include rules of procedure or the establishment of committees to manage intergovernmental matters or provide advice about them.

${ }^{81}$ Interview with Ato Mebeiratu Belay, policy analysis and plan officer, Addis Ababa, Feb. $18 / 2014$.

${ }^{82}$ Solomon Negussie, supra note 4, p 104

${ }^{83}$ Ronald H. Neumann and T. Russell Robinson (2006). The Structures and Conduct of Intergovernmental Relations, in the Richard M. Bird and François Vaillancourt, on "The International Bank for Reconstruction and Development Perspectives on Fiscal Federalism" pp. 66-67, p. 66.

${ }^{84}$ Ibid. 
In the absence of legislation, intergovernmental agreements, which typically are used to implement policy decisions, may also be used to establish intergovernmental arrangements for the performance of a variety of functions. These include consultation on identifying issues; preparation of common policy option; coordination, administration, and monitoring of issues; and the establishment of rules of procedure. This agreement may also establish forums which enable an intergovernmental political body or a group of officials to carry out IGR on either a one-time, regular and continuing basis. ${ }^{85}$

In light of the discussion above, institutions that are authorized to organize intergovernmental relationship seem imprecise in Ethiopia. However, there are formal and informal intergovernmental relationships which have been developed through time. There is an institution, the House of Federation, which invokes constitutional inference to organize IGR ${ }^{86}$ At the same time there is also an institution -the Ministry of Federal Affairs- that makes reference to legislation to organize IGR and establish intergovernmental department within its internal structure. ${ }^{87}$ The third category of institutions that have organized intergovernmental relations have made the intergovernmental convention as a legal base to organize IGR. ${ }^{88}$ This is usually described as a sector by sector interaction which is backed by memorandum of understanding duly signed by both levels of government representatives. This document serves as a legal basis to make their interaction formal.

\subsubsection{House of Federation}

The House of Federation is responsible to find solutions to disputes or misunderstandings that may arise between regional states. ${ }^{89}$ For instance, if a border dispute arises between two or more states; it is the mandate of the House to organize a forum for disputant-states to negotiate and settle the issue amicably. ${ }^{90}$ The House facilitates such forums and umpires both sides to get the issues resolved. If this attempt fails, the House can render decision to resolve such disputes on the basis of settlement patterns and the wishes of the peoples concerned ${ }^{91}$ within the time frame laid down under the Constitution. ${ }^{92}$

\footnotetext{
${ }^{85}$ Ibid.

${ }^{86}$ Interview with Ato Yakob, Acting Director of Intergovernmental Relations Directorate at House of Federation, Addis Ababa, Feb. 17/2014.

87 Interview with Ato Tsegabrihan Tadesse, Intergovernmental Relations Directorate General at Ministry of Federal affairs, Addis Ababa, Feb. 19/2014.

${ }^{88}$ Interview with Ato Mebeiratu Belay, policy analysis and plan officer, Addis Ababa, Feb. $18 / 2014$.

${ }^{89}$ See article 62 (6) of the FDRE Constitution.

${ }^{90}$ Interview with Ato Yakob Bekele, Acting Director of Intergovernmental Relations Directorate at the House of Federation, Addis Ababa, Feb. 17/2014.

${ }^{91}$ See article $48(1)$ of the FDRE Constitution.
} 
The House is also empowered to decide on issues pertaining to the rights of nations, nationalities and peoples to self-determination, including the right to secession in accordance with provisions of the Constitution. ${ }^{93}$ This mandate demands that regional states which have a problem of misunderstanding with one another in dealing with their matter before the House, decide their issues in accordance with the Constitution. The House may organize a forum for disputant-states to negotiate and resolve the issue amiably. This negotiation may include efforts of persuading the parties to renounce their intention of secession.

The other power of the House which involves intergovernmental relation relates to revenue sharing and grant allocations. The House is empowered to decide the division of revenues derived from joint Federal and State tax sources and the subsidies that the Federal Government may provide to the States. ${ }^{94}$ It decides the share of each level of government from joint tax source, and allocates the share of the regional states among individual regional states. The House also determines the allocation of federal subsidy among regional states. These matters can be source of conflict, and should be decided by consensus to maintain the social cohesion among the member states of the federation.

The House has organized both formal and informal IGR systems. The formal forums are essentially of two kinds: 'Forum of Speakers' and a joint forum of 'federation and regional states'. ${ }^{95}$ In the former case, as the name indicates, the participants are the speakers of both the federal houses and regional state councils. ${ }^{96}$ On the latter forum, the participants of the meeting are not limited to representatives of the regional states and the federal governments. ${ }^{97}$ It includes other stakeholders such as different staff, intellectuals and other invited guests. The most unique feature of their participation is that the invited guests are not passive participants of the meeting. They can forward their views during the meeting like any 'legitimate' participant or permanent member of the forum.

The federation units are expected to attend the IGR forum whether the agenda concerns a given state or not. This seems to have the rationale that units of the federation can draw lessons from states which have encountered problems. Most of these conferences are chaired by federal government officials. The regional states participate on the agenda set up by the House. The

\footnotetext{
${ }^{92}$ See article 48(2) of the FDRE Constitution.

${ }^{93}$ See article 62 (3) of the FDRE Constitution.

${ }^{94}$ See article 62(7) of the FDRE Constitution.

${ }^{95}$ Interview with Ato Yakob Bekele, Acting Director of Intergovernmental Relations Directorate at the House of Federation, Addis Ababa, Feb. 17/2014.

${ }^{96}$ Ibid.

${ }^{97}$ Ibid.
} 
role of the states is limited to forwarding their reflections on each agendum designed by experts. ${ }^{98}$

However, the IGR forums organized by the House, seem 'general meetings' rather than an IGR forums. Theses forums set broad agenda. The chairperson attempts to narrow down the diverse points raised by the participants. And then, the chairperson identifies an agendum that is agreed by all and makes the floor open for further discussion on those issues in which the participants did not reach agreement. ${ }^{99}$ These meetings allow differences to be discussed and provide a platform for reaching consensus.

However, dissenting opinion is not encouraged in the forums. ${ }^{100}$ If there is a participant who has dissenting opinion, an effort will be made to convince $\mathrm{him} / \mathrm{her}$. The party line adds its own impact for this. The opinion of the majority prevails over any dissenting opinion. This is known as "consensus dialogue". The other issue is the effect of the decision. The decision is binding on both sides: the participating state and the absent state/s. The minutes of the forum is sent to all regions the next day. After setting out a strategy and action plan, the issue may be returned to all regional states for implementation. Failure to attend the IGR forum will not entail any consequence, and the decision is binding even in the absence of a given state. ${ }^{101}$

\subsubsection{Ministry of Federal Affairs}

The Ministry of Federal Affairs is the other federal body which has engaged in organizing IGR. It has established a section in charge of formalizing IGR. It has also organized IGR forums. The ministry is working toward the establishment of IGR sections within each federal ministry and its respective counterpart at regional bureaus. ${ }^{102}$ This is part of the pursuits of institutionalizing sector by sector intergovernmental interactions. The Ministry's power of organizing IGR forums stems from its mandate and duties embodied in Proclamation No. 691/2010. Pursuant to this legislation, the Ministry of Federal Affairs has the powers and duties to cooperate with concerned federal and regional state organs in maintaining public order. ${ }^{103}$

Based on this mandate, the Ministry has organized a forum on peace and security. Participants of the forum are representatives of the federal and peace and security office heads of the regional states. Each region is represented by

\footnotetext{
${ }^{98}$ Ibid.

${ }^{99}$ Ibid.

${ }^{100}$ Ibid.

101 Ibid .

${ }^{102}$ Interview with Ato Tsegabrihan Tadesse, Intergovernmental Relations Directorate General at the Ministry of Federal Affairs, Addis Ababa, Feb. 19/2014.

103 See article 14(1)(a), Proclamation 691/2010.
} 
three representatives. ${ }^{104}$ This forum is active in exchanging information and is backed by a memorandum of understanding which clearly defines the role of each level of government. Usually, they meet every three months to evaluate their performance, identify problems encountered and determine directions for future action. ${ }^{105}$ The forum is chaired by the federal government, and the states have the right to raise issues they think important to be discussed at the forum. ${ }^{106}$

The second forum organized by the Ministry is the logical extension of the constitutional entitlement that requires government to provide special assistance to Nations, Nationalities, and Peoples of the least advantaged in economic and social development. ${ }^{107}$ On behalf of the Federal government, the Ministry is authorized to provide assistance to regional states particularly to those regional states which deserve special support. ${ }^{108}$ Furthermore, the Ministry coordinates, integrates and follows up supports given by other federal organs to the regional states. ${ }^{109}$ There are also formal IGR forums which are organized by the federal special support board sector. Normally, this seems to involve a holistic form of support to enhance their capacity. They meet every three months at the head level and there are monthly meetings at the level of technical staff. The support of these technical experts ranges from capacity building to issues of how to plan, implement and report the same. ${ }^{110}$

The Ministry is also empowered to facilitate the resolution of disputes arising between regional states. ${ }^{111}$ In this regard, it is obliged to make sure that its acts are not prejudicial to the power of the House of Federation as stated in Articles 48 and 62(6) of the Constitution. ${ }^{112}$ By virtue of Proclamation No. 610/2010, "the Ministry of Federal Affairs shall have the powers and duties to serve as a focal point in creating good federal-regional relationship and cooperation based on mutual understanding and partnership and thereby strengthening the federal system". ${ }^{113}$ The Proclamation indicates the institution that serves as a focal point

\footnotetext{
${ }^{104}$ Interview with Ato Sisay Melese, Culture of Peace Building Directorate Director at Ministry of Federal Affairs, Addis Ababa, Feb. 19/2014.

105 Ibid.

${ }^{106}$ Interview with Ato Tsegabrihan Tadesse, Intergovernmental relations Directorate General at Ministry of Federal Affairs, Addis Ababa, Feb. 19/2014.

${ }^{107}$ See article 89(4) of the FDRE Constitution.

${ }^{108}$ See article 14(1)(f), Proclamation 691/2010.

${ }^{109}$ See article 14(1)(g), Proclamation 691/2010.

110 Interview with Ato Tsegabrihan Tadesse, Intergovernmental relations Directorate General at Ministry of Federal Affairs, Addis Ababa, Feb. 19/2014.

${ }^{111}$ See article 14(1)(b), Proclamation 691/2010.

${ }^{112}$ See article 14(1)(b), Proclamation 691/2010.

${ }^{113}$ See article 14(1)(e), Proclamation 691/2010.
} 
to organize IGR. ${ }^{114}$ It also demands that the federal-state relationship should not be on the basis of hierarchy; rather, it should be on the basis of spirit of partnership and mutual understanding. ${ }^{115}$ As stated in the Proclamation, the overall objective of such relationship is to ensure "cooperation based on mutual understanding" and strengthen of the federal system.

\subsubsection{Sector by sector relationship}

In Ethiopia, virtually all ministries have their own family of intergovernmental mechanisms, and they have developed their own practice of cooperation and collaboration between the federal and regional governments. The structures, processes, and practices have been developed between different federal Ministries and their regional counterpart bureau in which all levels of government have a role. Thus, the Ministries of health, agriculture, education, trade and industry as well as regional sector bureaus have developed mechanisms and patterns to conduct intergovernmental relations that cover a wide range of functions. Although many of the concepts and functions are common across ministries, their roles and structures vary for a variety of reasons. The functions of the Ministry of Health and Ministry of Agriculture highlighted below provide examples of intergovernmental processes in the context of a sector by sector coordination and harmonization.

\section{a) Ministry of Heath with Regional Health Bureaus}

The Ministry of Health has the power and duty to formulate the country's health sector development programmes and to follow up and evaluate the implementation of the same. ${ }^{116}$ It supports the expansion of health services coverage and follows up and coordinates the implementation of health programs financed by foreign assistance and loans. ${ }^{117}$ The Ministry is also responsible to direct, coordinate and follow up the implementation of the country's health information system. ${ }^{118}$

Consistent with this mandate, the Ministry of Health is working with regional bureaus on prevention and control of diseases as well as availing health services for the public. ${ }^{119}$ The Ministry and the concerned regional bureaus have signed a

\footnotetext{
114 Ibid.

115 Ibid.

${ }^{116}$ Ibid. See article 29(1).

${ }^{117}$ See article 29(2).

${ }^{118}$ See article 29(3).

${ }^{119}$ Interview with Ato Mebeiratu Belay, policy analysis and plan officer, Addis Ababa, on Feb. 18/2014; and Interview with senior Expert (who wants anonymity) at Southern Nations, Nationalities and Peoples Regional state Health Bureau, Hawassa, March $14 / 2014$.
} 
memorandum of understanding which strengthens their collaboration. ${ }^{120}$ This document is expected to serve as a legal base for their interaction and cooperation. ${ }^{121}$ There is a regular meeting which is held every two months at the level of high officials. The participants in this forum are top management (council) of the Ministry and regional bureau heads under the chairmanship of Ministry of Health. ${ }^{122}$ In this case too, there are states who fail to attend the meeting even though they are bound by the decision of the forum, irrespective of their non-appearance. ${ }^{123}$ This forum is supported by a technical committee which is called Federal Ministry of Health and Regional Health Bureaus Joint Steering Committee (shortly abbreviated as FMOH-RHB). ${ }^{124}$

The committee collects information from each regional health bureau and identifies areas of priority. Based on the information gathered from each region, the committee identifies the common concerns of all the regions that should be discussed on the forum. ${ }^{125}$ The committee also identifies regions which need capacity building, financial support and experience sharing. ${ }^{126}$

Experts move to these regions to supervise their overall performance and provide appropriate technical support with a view to scaling up the performance of the regional states. These experts examine the overall performance the regional states and offer recommendations. Each region is expected to undertake its activities in accordance with the recommendations of the experts. Pursuant to this, each region prepares and submits its report both to its respective regional council and to the Ministry every month.

However, there are some states that delay their reports to the Ministry. In such cases, the state in default of reporting is notified to submit its report as soon as possible. If it fails to do so, this will be communicated to the Minister and the latter will write a letter, to which the regional states will instantly respond. The issue worth inquiring at this juncture is whether the regional states are obliged to submit a report to the Ministry? Failure of regional states to submit their report timely will be a ground to be evaluated by the federal government ${ }^{127}$ as if they are accountable to the federal government. This approach seriously erodes the spirit of partnership and mutual confidence that would be created otherwise between the tiers of governments.

\footnotetext{
${ }^{120}$ Ibid.

${ }^{121}$ Cited as a legal basis to institutional IGR forums.

${ }^{122}$ Interview with Ato Mebeiratu Belay, policy analysis and plan officer, Addis Ababa, Feb. $18 / 2014$

123 Ibid.

${ }^{124}$ Ibid.

125 Ibid.

${ }^{126}$ Ibid.

${ }^{127}$ Ibid.
} 


\section{b) Ministry of Agriculture with regional agriculture Bureaus}

Like the other ministerial offices, the federal Ministry of Agriculture has both formal and informal relationships with regional agriculture bureaus. The informal mechanisms include communication through letters, telephone and also video conferences. The formal mechanism involves the forums that are frequently held.

Activities that jointly engage the Ministry of Agriculture and regional agriculture bureaus include agricultural extension, natural resource and livestock development programs. ${ }^{128}$ The strategic oversight committee which follows up such joint engagements is composed of representatives from the Ministry of Agriculture, regional Agriculture Bureau and donors. ${ }^{129}$ These stakeholders together identify areas of priority and jointly prepare an annual plan derived from the Growth and Transformation Plan (GTP). The project has its own manual. The plan contains the respective roles of both levels of government. ${ }^{130}$ This joint plan and program is evaluated every three months'. ${ }^{131}$ After six months, each region is expected to submit its report to the Ministry.

There could also be other meetings (held twice a year) comprised of higher officials, experts and donors. ${ }^{132}$ The agenda is set by federal government experts. Here also, the role of the regional governments is limited to taking part in the meeting. Each meeting is chaired by the federal government officials, and head of agriculture bureau of the regional state -which serves as the venue of the meeting- becomes deputy chairperson. ${ }^{133}$ The federal government might take the forum as an opportunity to influence the agenda in favour of the federal government's areas of priority.

According to an opinion communicated to this author, it is the federal ministry that prepares the project and looks for funds, and that is why the federal government wants to have a tight control and hence chair the project. ${ }^{134}$ Even

128 Interview with Ato Getachew H/Mariam, senor information expert at Ministry of Agriculture, Addis Ababa, Feb. 18/2014.

${ }^{129}$ Interview with Ato Zena H/wold, planning and program directorate Director at Ministry of Agriculture, Addis Ababa, Feb. 18/2014.

${ }^{130}$ Interview with Ato Zena H/wold, planning and program directorate Director at Ministry of Agriculture held Addis Ababa, on Feb. 18/2014, and Interview with Ato Aylew Zenebe, Public Relation Expert at Southern Natation, nationality and People Regional state Agriculture Bureau, Hawassa, March 12/2014.

131 Ibid.

${ }^{132}$ Interview with Ato Zena H/wold, planning and program directorate Director at Ministry of Agriculture, Addis Ababa, Feb. 18/2014.

${ }^{133}$ Interview with Ato Aylew Zenebe, Public Relation Expert at Southern Nations, Nationalities and Peoples Regional state Agriculture Bureau, Hawassa, March 14/2014.

${ }^{134}$ Interview with Ato Zena H/wold, Director of Planning and Program Directorate at the Ministry of Agriculture, Addis Ababa, Feb. 18/2014. 
though the federal government prepares the plan and organizes the platform for discussion, the regional governments have a significant role in developing the project proposal. ${ }^{135}$ The program is implemented in their respective regions and they are the actual actors in implementing the program. This gives them the opportunity to execute projects in their own context subject to submitting periodic reports regarding their performance. In case there are representatives of the regional governments who fail to attend the conference, they will be bound by the decision of the summit. ${ }^{136}$

\subsubsection{Political parties as a channel of intergovernmental relations in Ethiopia}

The dominant arrangement which has been employed by the federal government to ensure federal influence on states and guarantee uniform application of policies is the political party channel. It can be argued that a disciplined party that dominates both levels of government is an asset for a divided country like Ethiopia. However, many writers consider this as an obstacle to a genuine federal structure. ${ }^{137}$ In practice, the hegemonic control of the party throughout Ethiopia is a problem.

The interaction between the central ruling party and regional member and affiliate parties is characterized by what Paulos calls "patron-clientism". 138 Regional parties are implementers of the policies adopted by the Ethiopian Peoples' Revolutionary Democratic Front (EPRDF). The ruling party has its own representatives in regional states. By directly communicating with these representatives, the federal government can monitor the implementation of federal policies, programs and plans in regional states, and to render assistance in the capacity building pursuits of the latter. This has led some to conclude that there is currently a de facto one party state. ${ }^{139}$

Although we can argue that EPRDF is a coalition of ethnic parties, and not a monolithic party, the total dominance of EPRDF at both levels of government in Ethiopia is obvious. This evokes the question as to what will happen if an opposition party manages to win elections at regional or federal level? In other

${ }^{135}$ Interview with Ato Aylew Zenebe, Public Relation Expert at Southern Nations, Nationalities and Peoples Regional state Agriculture Bureau, Hawassa, March 14/2014.

${ }^{136}$ Interview with Ato Zena H/wold, Director of Planning and Program Directorate at Ministry of Agriculture, Addis Ababa, Feb. 18/2014.

${ }^{137}$ Assefa Fiseha, (2006) supra note 35, p 116 ; see also Paulos Chanie (2007), What One Hand Giveth, the Other Hand Taketh Away: Ethiopia's Post-1991 Decentralization reform under neo-patrimonialism, Netherlands, Shaker publishing, p. 283.

${ }^{138}$ Paulos, Id., p. 284

${ }^{139}$ Merera Gudina (2007). 'Party politics and election in Ethiopia: 1991-2005' In Kassahun Berhanu and et al (eds.), Electoral politics, decentralized governance, and constitutionalism in Ethiopia. (Addis Ababa: Addis Ababa University Press. 
words, if an opposition party manages to win elections at regional a level and EPRDF wins at the federal level, some fear that the reasons for the collapse of the Soviet Union could be a prophesy to the Ethiopian federalism as well. ${ }^{140}$

Hence, what are the mechanisms of dealing with centrifugal forces if they dominate the political space? As Bekele quoted in Alem argues, if EPRDF falls from power, the federation will wither away with it. Indeed, such fears are grounded, since each ethnic group has the weapon of secession. In fact, such threat is something confirmed by EPRDF itself in its series of party meetings. ${ }^{141}$

One can anticipate a number of worst case scenarios. The collapse of the federation might be followed by civil war, military rule, or disintegration of the Ethiopian state. The potential for such negative scenarios calls for proactive strategic thinking and measures that can enhance cooperation, trust and harmony. After a certain level of fragility, failed statehood may not stop at the level of a regional state or a zone but can go further down to the smallest demarcation point of 'identity' because at that stage denominations such as shared language and religion do not guarantee unity and peace as is the case in Somalia and other countries. While the Soviet Union scenario was fragmentation of the states, fragility and failed statehood can bring about scenarios that are even worse.

One of the areas that show potential danger of deadlock is the arrangement of intergovernmental fiscal transfer. By African standards, regional officials in Ethiopia are less confident to challenge the federal government on constitutional grounds. ${ }^{142}$ Despite a single party dominance, however, we have witnessed serious debates in the House of Federation (HoF) in matters of fiscal transfer. In this case, Solomon's analysis of the potential tension of revenue secession in light of the experiences of other countries is worth mentioning. ${ }^{143}$ In settings of different parties controlling regional states, there could be serious inter-ethnic party conflict on these issues.

The 2001 Tigray People's Liberation Front (TPLF) crisis, as many writers observed, is illustrative of the fragile nature of the federation in general and the status of intergovernmental relations in particular. ${ }^{144}$ EPRDF itself, as stated in its series of party meetings, appeared to have been shocked and took subsequent

\footnotetext{
${ }^{140}$ Ibid

${ }^{141}$ Alem Habtu (2003). Ethnic Federalism in Ethiopia: Background, Present Conditions and Future Prospects. Paper Submitted to the Second EAF International Symposium on Contemporary Development Issues in Ethiopia, July 11-12, The Ghion Hotel Addis Ababa.

${ }^{142}$ Merera Gudina, supra note 139.

${ }^{143}$ Solomon Negussie supra note 4, p. 266

${ }^{144}$ Young and Medhane (2003) 'TPLF: Reform or Decline', in Review of African Political Economy,30:97
} 
measures, which were seen by some as implementing the constitutional provisions to fill the existing gaps and by some as extra-constitutional centralization of power. Some of the notable steps taken were the creation of federal police force in the regions, replacement of delegated court structure with dual court structure, the creation of Ministry of Federal affairs, and passage of a proclamation for federal intervention into the regions; at one point EPRDF had announced its intentions to transform the ethnic based parties into nationwide parties. $^{145}$

In the midst of such challenges, Tom Patz saw phenomena which emerged from the 2001 party crisis, such as the rise in the self-confidence and selfassurance of regional states as well as the formation of several committees, work groups and coordination mechanisms. ${ }^{146}$ He advises states to understand the inherent complexities of a federal system and to learn how to manage and solve conflicts by developing the culture of dialogue and consensus building. Thus, institutionalized intergovernmental relations will enable participation and consensus building on matters of shared functions. This may avoid blackmail and conspiracy by some regional parties to manipulate ethnic identity for particular purposes.

\subsection{IGR and its implication on state autonomy in Ethiopia}

Hundreds of meetings each year, uncountable informal contacts, a varied and complex intergovernmental cooperation are the nature of intergovernmental relations in Ethiopia today. ${ }^{147}$ The increasing number of multilateral and bilateral intergovernmental agreements and partnerships indicate the intergovernmental activities in all policy areas. With the shift to the signing of several intergovernmental agreements and pressure for policy and administrative collaboration, one might expect significant changes both in the formal intergovernmental machinery and informal interactions. However, there has been little examination of the implications of such changes of formal intergovernmental machinery or of informal intergovernmental networks on the autonomy of the states. This implication can be viewed form the following perspectives.

\footnotetext{
${ }^{145}$ Assefa Fiseha (2006), supra note 35, p. 273

${ }^{146}$ Patz, Tom (2005). 'Ethiopia's return to federalism' in federations, Vol.5 No.A-1, p144

${ }^{147}$ Interview with Ato Yakob, Acting Director of intergovernmental relations Directorate at House of Federation and Ato Tsegabrihan Tadesse, Intergovernmental relations Directorate General at Ministry of Federal Affairs, Addis Ababa, Feb 17/2014 and 19/2014 respectively.
} 


\subsubsection{Institutionalization Process}

The absence of an independent institution that is in charge of consolidating IGR leads to lack of regularity and continuity of interactions. For instance, some institutions make intergovernmental relation twice a year and others make it three times a year. Unless the regional government requests the assistance of the federal government, the forums are organized based on the schedule of the federal government and when the federal government deems it necessary to disseminate some lesson/information for the federation units. Or, it may take place when there is some urgent matter that the federal government desires to implement throughout the country or if there are national issues of sufficient substance to warrant a meeting.

The other point that needs consideration is requesting all regional states to participate in the meeting. Even more, representatives of all regional states are expected to participate on the IGR forums without inquiring whether the agenda only concerns a particular state or not. ${ }^{148} \mathrm{Had}$ it not been for the absence of formal institutions in charge of IGR, all federation-units would not have been called for IGR dialogues on every issue/matter. A federal ministry writes a letter to its counterpart as if the latter is subordinate to the former. This results in the development of unwanted hierarchical relationship between the two. Unconstructive cultures of superior-subordinate interaction freezes a spirit of partnership and erodes the autonomy of the states.

Moreover, the existence of a dominant political party system and the overriding mode of interaction between federal and state relations through the party channel undermine the establishment of formal institutional frameworks. As a result, formal intergovernmental relations are ultimately placed within the domains of party channel interactions thereby influencing the operation of the same. This continues to pose a challenge to the stability and integrity of formal intergovernmental relationships in the Ethiopian federation. ${ }^{149}$ Furthermore, the level of horizontal intergovernmental relations is even much underdeveloped, with the exception of informal cooperation of few regional states. ${ }^{150}$

\subsubsection{The role and power balance of the two tiers of government}

Despite some sections of the Constitution that suggests non-hierarchal relationship between the federal and regional states, in Ethiopia, what exists is a top-down federal system. The federal government has wide range of powers to

${ }^{148}$ It can also be argued that the participation of all states may have the advantage of creating the chance for experience sharing, they may contribute in generating innovative solutions, and learning from the forum they may also take necessary preventive measures to make sure that the same problem would not occur in their territory.

149 Assefa Fiseha (2009), supra note 11.

${ }^{150}$ Assefa Fiseha (2006), supra note 35, p. 274. 
undermine regional plans, and to intervene in regional administrations. Regional governments have not developed a strong sense in considering themselves as independent political actors. It appears that many inter-governmental meetings are dominated by federal government priorities.

One drawback of the current structures of IGR at the level of federal-state relations is that it is defined and practiced in 'hierarchical terms'. There is a clear top-down approach while the federal government is dealing with regional states in several matters. The state governments, both in terms of personnel and in the nature of responsibility, are less equipped compared to that of the federal government. Most of the time, it is the federal government which takes the lion's share in agenda-setting and organizing IGR forums. ${ }^{151}$ Besides, it is the federal government which chairs most of the conferences. All these verify that it is a hierarchical relation rather than equality that has been a key feature of IGR in Ethiopia.

\subsubsection{The invisible obligation to submit periodic reports}

Regional government officials are required to submit periodic reports on their performance. Their achievements are evaluated under the chairmanship of the federal government officials. These officials give feedback and direction about things that can/should be done and on the way forward. This may extend to the reporting of the inefficiency of the regional representatives to the regional government president's office which may result in the removal of the person in charge of the office. This undoubtedly amounts to eroding the autonomy of the regions and systematic reshuffling of the regional state officials. This is against the constitutional integrity of the regional states.

\section{Concluding Remarks}

Intergovernmental relation is important in installing the culture of negotiation, checking the centralization of government power, and enhancing the bargaining power of the regional states. Establishment of permanent forums for intergovernmental bond has a crucial role in negotiation, non-hierarchical exchange of information as well as facilitation of cooperation between the institutions of the two levels of government.

Regarding institutional framework of IGR in Ethiopia, the House of Federation invokes a constitutional basis to organize IGR. At the same time the Ministry of Federal Affairs invokes certain legislation as its legal basis to organize IGR. The third category of interaction which has been practiced uses intergovernmental agreement as a legal basis for organizing IGR. This is usually described as sector by sector interaction which is backed by the signing of

${ }^{151}$ Id., p. 391. 
memorandum of understanding. This document serves as a legal base to make their interaction formal.

Therefore, establishing an appropriate legal framework is essential to optimize the benefits of intergovernmental relationship. This legal framework must contain detail principles of cooperation in the course of concurrent or overlapping responsibilities. An independent institution should be established whose mandate is mainly to organize IGR on shared programs. Federations are expected to respond both to central priorities and to regional and local priorities; and each negotiation should be done on the spirit of partnership and equality rather than hierarchy.

Neutrality of the institution facilitates the coequality of the two tiers of government. The House of federation seems the appropriate institution to organize IGR in light of the participation of the regional governments in the House. Second, the House has constitutional mandate to organize IGR. If the existing dependence on the executive line remains unchanged, the focal point for IGR should be the prime-minister's office owing to its enhanced opportunity to give binding decisions and its ability to control the execution of decisions.

A federal government interacts and collaborates with a regional government either individually or jointly. Therefore, a given state should be expected to attend IGR forums only if the matter concerns it. Otherwise, it is unnecessary to demand and oblige every regional state to partake on the issue that does not add substantial value to its interests and concerns. The role of invited guests in IGR forums should also be sufficiently defined. The IGR forums are basically meant to coordinate the policies of the federal and the regional states on the shared programs. The federal government and the state governments identify their role on the program and reach a consensus. The role of invited guests should thus be limited to giving opinion rather having a say same as the stakeholders, i.e. federal and regional government representatives. 